\title{
Diaparsis jenningsi, a new species of Tersilochinae (Hymenoptera: Ichneumonidae) from Australia
}

\author{
Diaparsis jenningsi - новый виА терзилохин \\ (Hymenoptera: Ichneumonidae: Tersilochinae) из Австралии
}

\begin{abstract}
A.I. Khalaim
A.И. Халаим

Zoological Institute, Russian Academy of Sciences, Universitetskaya nab. 1, St. Petersburg, Russia. Зоологический институт РАН, Университетская наб. 1, Санкт-Петербург, Россия.

Universidad Autónoma de Tamaulipas, Cd. Victoria, Tamaulipas, México. E-mail: ptera@mail.ru

KEY WORDS: Australia, Diaparsis, new species, taxonomy.

КЛЮЧЕВЫЕ СЛОВА: Австралия, Diaparsis, новый вид, систематика.
\end{abstract}

ABSTRACT. A new tersilochine species, Diaparsis (Diaparsis) jenningsi sp.n., is described and illustrated from South Australia.

РЕЗЮМЕ. Новый вид наездников-терзилохин, Diaparsis (Diaparsis) jenningsi sp.n., описан из Южной Австралии.

\section{Introduction}

Australian fauna of the subfamily Tersilochinae was briefly reviewed by Gauld [1984] who reported from Australia nine genera, Allophrys Förster, 1869, Areyonga Gauld, 1984, Diaparsis Förster, 1869, Horstmannolochus Gauld, 1984, Petilochus Gauld, 1984, Phradis Förster, 1869, Probles Förster, 1869, Sathropterus Förster, 1869 (was recently synonymized with Aneuclis Förster, 1869, see Khalaim, 2018), and Stethantyx Townes, 1971 with about 27 species in total, but only six of these species were named while others were mentioned as morphospecies. Later, Khalaim [2004, 2008, 2017] described from Australia the genus Australochus Khalaim, 2004 with two species, recorded the genus Barycnemis Förster, 1869 with one new species, and described one species of Diaparsis and one species of Phradis.

The large almost worldwide genus Diaparsis (unknown only from the Neotropical region) comprises about 90 described and many undescribed species [Yu et al., 2016]. Gauld [1984] mentioned nine species of Diaparsis in Australia, but only one abundant species, D. proterva Khalaim, 2008, was recently described [Khalaim, 2008, 2015]. The aim of this study is to describe a second species of Diaparsis from South Australia.

\section{Material and Methods}

The holotype of the new species is deposited in the Texas A\&M University, Texas, USA (TAMU). The morphological terminology follows that of Khalaim [2011]. Colour photographs were taken at the Zoological Institute of the Russian Academy of Sciences with a Canon EOS 70D digital camera attached to an Olympus SZX10 stereomicroscope; partially focused images were combined using Helicon Focus 6.7.1 Pro software.

\section{Results}

Diaparsis (Diaparsis) jenningsi Khalaim, sp.n. Figs 1-9.

MATERIAL EXAMINED. Holotype: + , Australia, South Australia [State], Kangaroo Is., Flinders Chase National Park, Rocky River, 6 January 1990, coll. R. Wharton (TAMU).

DESCRIPTION. Female. Body length $3.5 \mathrm{~mm}$. Fore wing length about $2.5 \mathrm{~mm}$.

Head roundly tapered behind eyes in dorsal view; temple 0.6 times as long as eye width. Eyes glabrous. Clypeus unusually small (Fig. 3), 2.5 times as broad as long and 0.65 times as broad as face, flat, with ventrolateral margins slightly concave; clypeus smooth and shining in lower $2 / 3$, scabrous with fine inconspicuous punctures in upper third, separated from face by distinct groove. Mandible strongly tapered, twisted, with upper tooth much longer than the lower; lower tooth small. Malar space almost as long as basal mandibular width. Antennal flagellum (Fig. 2) filiform, with 17 flagellomeres; subbasal flagellomeres 1.7-1.8 times and subapical flagellomeres 1.2-1.3 times as long as broad. Face with very weak median convexity in upper part. Face and frons distinctly granulate, dull, with fine punctures which are mostly indistinct because of granulation. Vertex finely gran-

How to cite this article: Khalaim A.I. 2018. Diaparsis jenningsi, a new species of Tersilochinae (Hymenoptera: Ichneumonidae) from Australia // Russian Entomol. J. Vol.27. No.4. P.399-402. doi: 10.15298/ rusentj.27.4.07 
ulate, dull, with fine punctures. Temple more or less smooth, weakly shining, with fine inconspicuous punctures. Occipital carina fine, complete, mediodorsally notably pointed in dorsal view (Fig. 4, arrow). Hypostomal carina present; lower part of occiput with rather strong subvertical striae.

Mesoscutum (Fig. 7) densely granulate, dull, with fine punctures which are mostly indistinct because of granulation. Scutellum densely granulate, dull, weakly convex in lateral view, with lateral longitudinal carinae developed only at its extreme base (Fig. 7). Notaulus with rather long wrinkle on anterolateral side of mesoscutum. Mesopleuron entirely densely granulate, dull, with fine punctures which are mostly indistinct because of granulation. Foveate groove (Fig. 5) extending in anterior half of mesopleuron, strongly oblique (about $45^{\circ}$ ), broad but shallow, not reaching anterior margin of mesopleuron, with distinct transverse wrinkles. Propodeum entirely densely granulate, dull, impunctate (Fig. 6). Propodeum with very weak basal keel which is almost 0.7

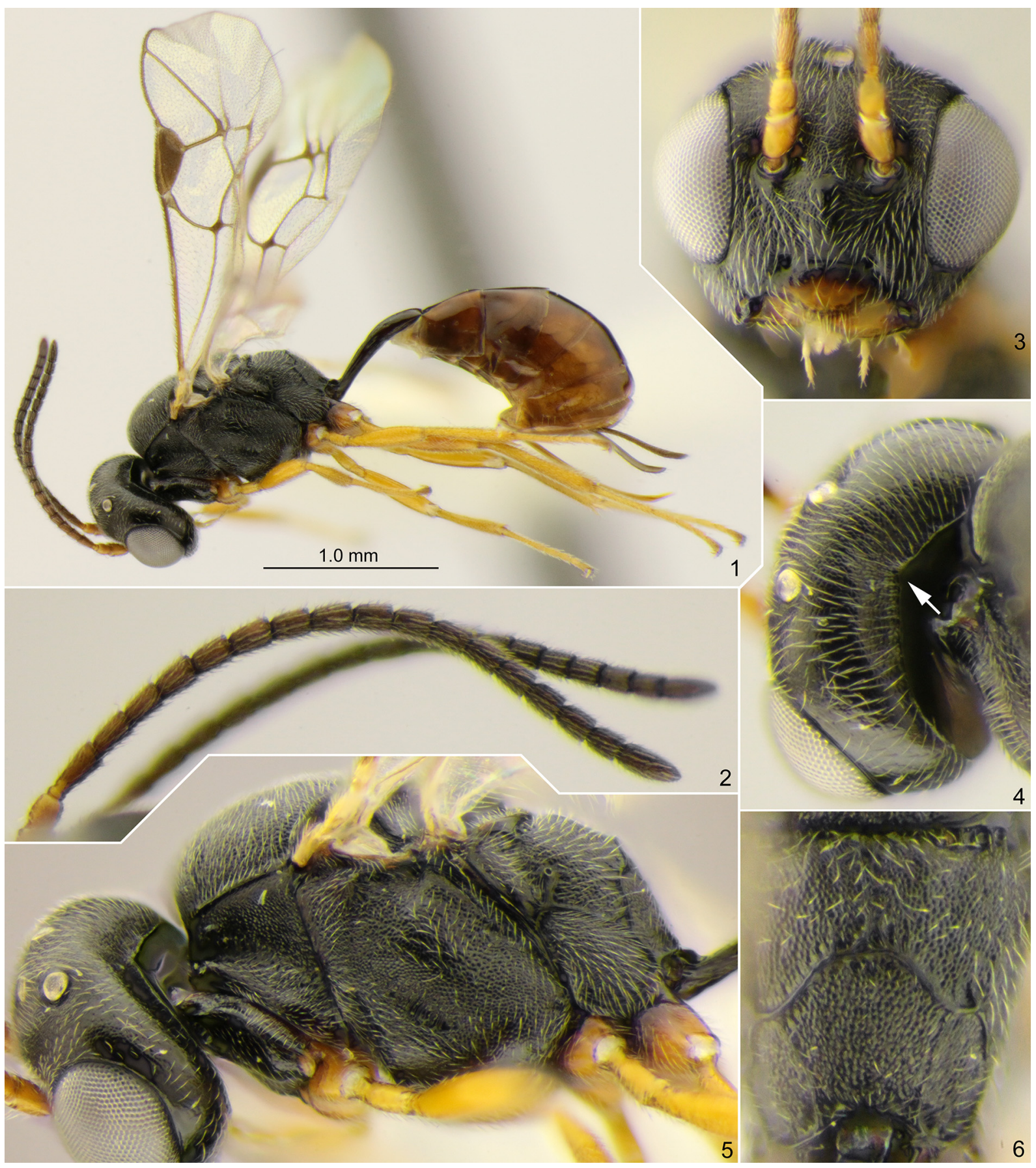

Figs 1-6. Diaparsis jenningsi sp.n., + , holotype: 1 - habitus, lateral view; 2 - antennae, lateral view; 3 - head, front view; 4 - head, postero-dorso-lateral view; 5 - head and mesosoma, lateral view; 6 - propodeum, dorsal view.

Рис. 1-6. Diaparsis jenningsi sp.n., , , голотип: 1 - габитус, сбоку; 2 - антенны, сбоку; 3 - голова, спереди; 4 - голова, сзади, сверху и сбоку; 5 - голова и мезосома, сбоку; 6 - проподеум, сверху. 

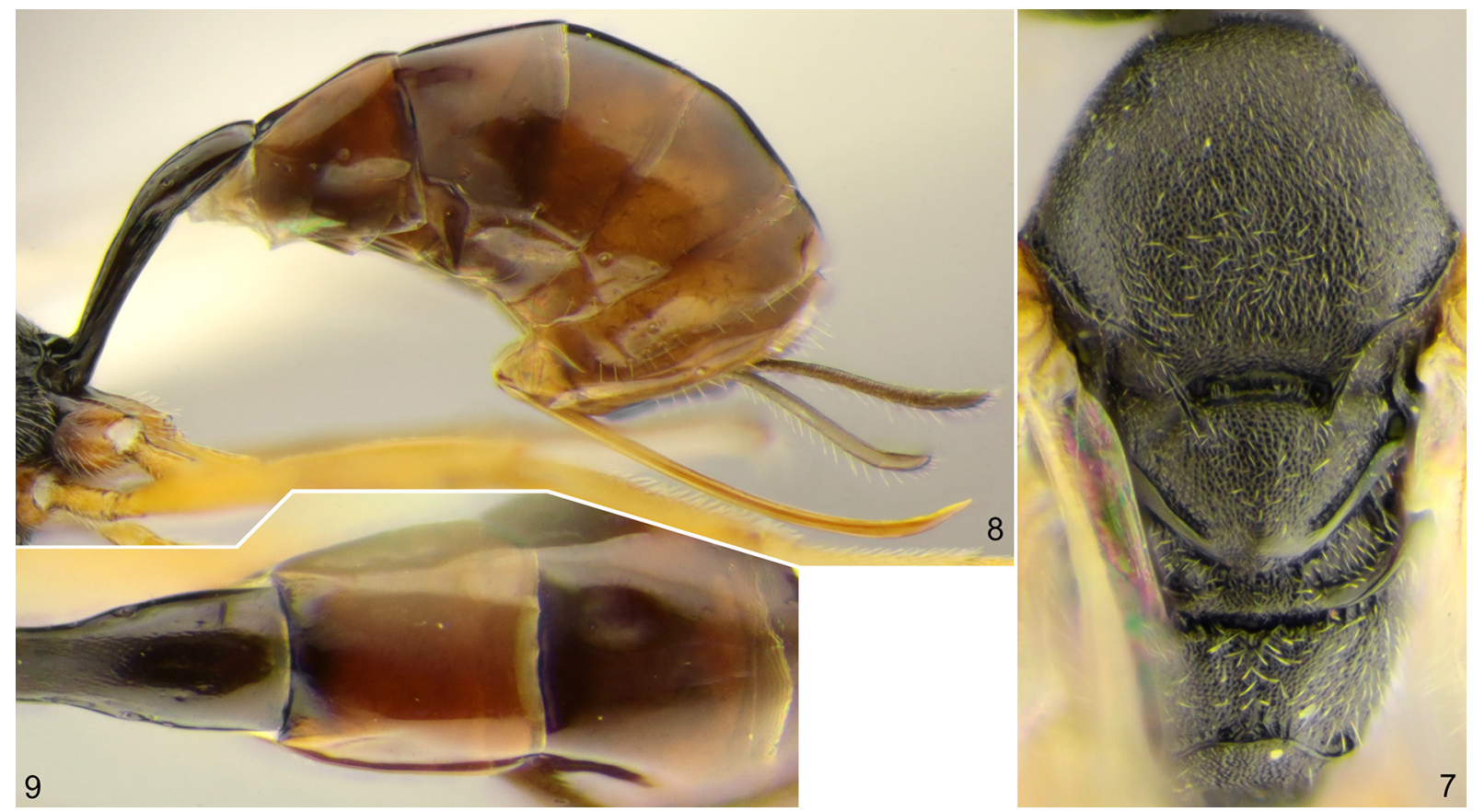

Figs 7-9. Diaparsis jenningsi sp.n., + , holotype: 7 - mesosoma, dorsal view; 8 - metasoma, lateral view; 9 - base of metasoma, dorsal view. Рис. 7-9. Diaparsis jenningsi sp.n., , голотип: 7 - мезосома, сверху; 8 - метасома, сбоку; 9 - основание метасомы, сверху.

times as long as apical area. Propodeal spiracle separated from pleural carina by about 3.5 times diameter of spiracle (Fig. 5). Apical area flat, very widely rounded anteriorly (Fig. $6)$; apical longitudinal carinae distinct posteriorly and very weak, evanescent anteriorly.

Fore wing with second recurrent vein distinctly postfurcal. Intercubitus thick, shorter than abscissa of cubitus between intercubitus and second recurrent vein. First abscissa of radius as long as width of pterostigma. First and second abscissae of radius meeting at right angle. Metacarpus not reaching tip of fore wing. Hind wing with nervellus slightly reclivous. Legs slender. Hind femur 0.85 times as long as tibia. Tarsal claws rather strongly curved, not pectinate.

First metasomal tergite 3.0 times as long as posteriorly broad; petiole slightly depressed, trapeziform in cross-section in centre, laterally with weak striae, dorsally smooth; postpetiole smooth, in dorsal view widened and distinctly broader than petiole (Fig. 9). Glymma elongated, isolated, situated in centre of first tergite (Fig. 8). Second tergite almost 1.4 times as long as anteriorly broad (Fig. 9). Thyridial depression shallow, slightly elongated. Ovipositor short, robust, weakly upcurved in basal 0.8 and rather strongly upcurved at apex, with shallow dorsal subapical depression, without teeth ventrally (Fig. 8); sheath 0.85 times as long as first tergite and 0.8 times as long as hind tibia.

Head and mesosoma black; mouthparts yellow; lower 0.7 of clypeus brownish yellow; mandible brownish yellow with teeth and mark at base dark reddish brown. Antenna with scape and pedicel yellow; flagellum fuscous, paler basally on ventral side; tegula yellow. Wings hyaline, pterostigma brown with small pale spots proximally and distally. Legs brownish yellow, hind coxa strongly darkened with brown at basal half. First metasomal tergite black with brown tinge; following tergites predominantly brown, darker dorsally and yellowish laterally.
Male. Unknown.

COMPARISON. The new species differs from another Australian species of this genus, D. proterva, by its twisted mandible, unusually small clypeus (Fig. 3) and short ovipositor with apex strongly upcurved (Fig. 8). The new species also possesses a remarkable, pointed mediodorsally occipital carina (Fig. 4, arrow).

ETYMOLOGY. The species is named in honour of the Australian entomologist, John Jennings (the University of Adelaide, Australia).

DISTRIBUTION. South Australia.

ACKNOWLEDGEMENTS. I am thankful to John D. Oswald and Karen Wright (TAMU) for the loan of valuable material of Tersilochinae. This work was supported by the Russian Foundation for Basic Research (grant no. 16-0400197) and the State Research Project no. AAAA-A17117030310210-3.

\section{References}

Gauld I.D. 1984. Subfamily Tersilochinae. In: An Introduction to the Ichneumonidae of Australia // Bulletin of the British Museum (Natural History) (Entomology). Vol.895. P.304-316.

Khalaim A.I. 2004. New tersilochines from Australia and New Zealand (Hymenoptera: Ichneumonidae, Tersilochinae) // Zoosystematica Rossica. Vol.13. No.1. P.43-45.

Khalaim A.I. 2008. A new species of the genus Diaparsis Förster from Australia (Hymenoptera: Ichneumonidae: Tersilochinae) // Zoosystematica Rossica. Vol.17. No.1. P.83-84.

Khalaim A.I. 2011. Tersilochinae of South, Southeast and East Asia, excluding Mongolia and Japan (Hymenoptera: Ichneumonidae) // Zoosystematica Rossica. Vol.20. No.1. P.96-148.

Khalaim A.I. 2015. To the study of Australian Tersilochinae (Hymenoptera: Ichneumonidae) // Russian Entomological Journal. Vol.24. No.1. P.77-83. 
Khalaim A.I. 2017. New species of the genera Australochus Khalaim and Phradis Förster (Hymenoptera: Ichneumonidae: Tersilochinae) from Australia // Russian Entomological Journal. Vol.26. No.4. P.327-331.

Khalaim A.I. 2018. The genera Allophrys Förster and Aneuclis Förster (Hymenoptera: Ichneumonidae: Tersilochinae) of Vietnam // Zootaxa. Vol.4378. No.3. P.414-428. doi:10.11646/zootaxa.4378.3.9

Yu D.S.K., van Achterberg C., Horstmann K. 2016. Taxapad 2016 , Ichneumonoidea 2015. Database on flash-drive. Nepean, Ontario, Canada. 